\title{
The Conscientious Objector Exemption: Administrative Procedures and Judicial Review
}

\author{
Ralph Reisner
}

\begin{abstract}
It is always difficult to devise procedures which will be adequate to do justice in cases where the sincerity of another's religious convictions is the ultimate factual issue. It is especially difficult when these procedures must be geared to meet the imperative needs of mobilization and national vigilancewhen there is no time for "litigious interruption."
\end{abstract}

When Congress confronted the problem of fashioning a new military conscription law in 1940, legislative recognition of the special claim of the religious objector was already a deeply rooted tradition. ${ }^{2}$ What remained in issue, however, was the breadth and scope of the exemption and, perhaps as important, the type of administrative mechanism that would be employed to control its issuance.

In its final form, the $1940 \mathrm{Act}^{3}$ departed significantly in both substance ${ }^{4}$ and procedures from the scheme of earlier draft legislation. In apparent recognition of the particular difficulties inherent in the administration of the conscientious objection exemption, Congress au-

Ralph Reisner is Professor of Law, The University of Illinois.

The author wishes to acknowledge the helpful suggestions of his colleague, Herbert Semmel. A grant from the University of Illinois Research Board provided the financial support for the collection of empirical data upon which a part of this article is based.

1 United States v. Nugent, 346 U.S. I, 10 (1953).

2 See generally E. WRIGRT, Consctentious ObJectors in the Civir WAR (1931); 1 U.S. Selectrve SeRvice System, Conscientious ObJectors (Monograph No. 11, 1950); Russell, Development of Conscientious Objector Recognition in the United States, 20 GEO. WASH. L. REv. 409 (1952).

3 Selective Training and Service Act of 1940, ch, 720, 54 Stat. 885 (1940).

4 Exemption under the Selective Service Act of 1917 was limited to members of "any well-recognized religious sect or organization." Ch. 15, § 4, 40 Stat. 76 (1917). Moreover, the exemption was only partial: those exempted were inducted and required to perform "noncombatant" duties. The 1940 Act eliminated the requirement of membership in a recognized pacifist sect. Instead, exemption was extended to anyone whose opposition was the product of "religious training and belief" Ch. 720, \& 5 (g), 54 Stat. 889 (1940). The 1940 Act varied in another significant respect. Unlike the earlier law, it provided for a possibility of total exemption from military service. Those exempted were, however, as under present law, assigned to civilian service of "national importance" for an equivalent length of time. 
thorized a set of special appellate procedures. Any appeal from the denial of a claim for conscientious objector status was to be submitted to the Department of Justice which, after a comprehensive investigation $^{5}$ and a personal appearance hearing, ${ }^{6}$ would render an advisory opinion to the appeal board that had referred the case. ${ }^{7}$

Between 1940 and 1967 the Department of Justice played a dominant role in the administration of this particular exemption. Of the 700 cases processed per year, ${ }^{8}$ more than 70 per cent resulted in recommendations which sustained the registrants' claims ${ }^{9}$ and in effect rejected the local board classifications. It has been estimated that the

5 The investigations, while somewhat varied in scope and depth, consisted in the main of interviews with a wide range of persons who had some contact with the registrant. The interviews typically delved into the impressions of the registrant's minister, relatives, friends, neighbors, teachers, and employers. The investigation usually went back several years and extended to any community in which the registrant had resided. On completion of the investigation the FBI submitted a comprehensive report to the Department of Justice. Though the report itself was made available only to officials of the Department of Justice, the registrant received a "fair résumé." See United States v. Nugent, 346 U.S. 1,6 (1953). The résumé generally differed from the original report only in the omission of the names and addresses of the informants.

6 The Selective Service Act provided that upon the referral of a claim, the Department of Justice, after "appropriate inquiry," should hold a hearing "with respect to the character and good faith of the objections of the person concerned." Selective Training and Service Act of 1940, ch. 720, $\$ 5(\mathrm{~g}), 54$ Stat. 889 (1940). Each hearing was conducted by one of the department hearing officers who was generally a private attorney holding a non-remunerative appointment. The hearings contemplated under the Act were in the nature of administrative proceedings and were intended to be conducted in an "informal, non-technical and flexible" manner. OfFice of THE ATtorney General, Mearo No. 41 (REvISED) § 104.1 (April 2, 1956). While the registrant could be accompanied by "one attorney or other personal advisor" such individual could not "object to any question or make any argument concerning any phase of the proceeding." Id. § 104.5. The registrant could introduce testimonial or documentary evidence in addition to that which he might have submitted previously to his local board. Id. § 104.4-5. Upon conclusion of the hearing the hearing officer filed a report with the appropriate section of the Department of Justice. In addition to a recommendation, the report contained a recitation of findings and conclusions of law. These reports were regarded as interdepartmental communications and not made available to the registrant.

7 The hearing officer's recommendation was not binding on the Department of Justice. Each hearing officer's report was carefully reviewed by one of the staff attorneys of the Conscientious Objector section. In approximately $75 \%$ of the cases the Department followed the hearing offcer's recommendation. Rabin, Do You Believe in a Supreme BeingThe Administration of the Conscientious Objector Exemption, 1967 Wrs. L. REv. 642. Professor Rabin found that the intervention of this section of the Department of Justice allowed the evolution and application of a uniform standard and permitted the complex factual and legal issues to be determined by a legally trained staff of unmatched experience. Id. at 663.

8 Average case load over ten year period (1956-1966). Data supplied by the Conscientious Objector section of the Department of Justice.

o Data supplied by the Conscientious Objector section of the Department of Justice. 
appeal boards followed these recommendations from the Department of Justice in 90 per cent of all cases. ${ }^{10}$

A sharp rise in the conscription rate in the late spring of $1965^{11}$ was followed by a significant increase in the number of appeals from the classification action of local boards; ${ }^{12}$ and a corresponding increase in the number of cases referred to the Department of Justice. ${ }^{13}$ Within months the accumulation of cases waiting to be processed had mushroomed. In practical terms this meant that where previously a case could be fully processed in three to six months, by mid-1966 it took approximately eighteen months. This inability to cope satisfactorily with the increased load must in large part be attributed to the failure of the Office of the Attorney General to anticipate events and to augment the staff in the appropriate section of the agency. In some measure it must also be attributed to a weakness in the system itself: the use of uncompensated, volunteer hearing officers over whom the Department of Justice had minimal control, and who accordingly worked at their own pace.

The back-up of cases was criticized by the Givilian Advisory Panel on Military Manpower Procurement. Its report to the House Committee on Armed Services in February, 1967 contained the following observation and recommendation:

10 Gonzales v. United States, 364 U.S. 59, 72 (1960). See also Smith \& Bell, The Conscientious Objector Program-A Search for Sincerity, 19 U. PrTT L. REv. 695, 702 (1958).

11 The following table illustrates the change that took place in 1965:

Total Calls for Inductees, 1965

$\begin{array}{lc}\text { Month } & \text { Calls for Inductees } \\ \text { Jan. } & 5,400 \\ \text { Feb. } & 3,000 \\ \text { March } & 7,900 \\ \text { April } & 13,700 \\ \text { May } & 15,100 \\ \text { June } & 17,000 \\ \text { July } & 17,100 \\ \text { Aug. } & 16,500 \\ \text { Sept. } & 27,400 \\ \text { Oct. } & 33,600 \\ \text { Nov. } & 38,350 \\ \text { Dec. } & 40,200\end{array}$

1966 DIR. SEL. SERv. ANN. REP. 86

12 The number of appeals in all classification categories increased from 9,741 in fiscal 1965 to 49,718 in fiscal 1966, an increase in excess of 500\%. 1967 DIR. SEL. SERv. ANN. REP. 26.

13 The number of cases referred to the Department of Justice increased approximately $250 \%$ from fiscal 1965 to fiscal 1966. Data supplied by Conscientious Objector section of Department of Justice. 
Information provided the Panel indicated that some appeals by conscientious objectors that had been referred to the Department of Justice for investigation and advisory opinions had resulted in delays in processing exceeding one year. This delay in the processing of conscientious objectors' appeals appears unwarranted and lends itself to possible utilization as a delaying tactic by individuals who desire to evade military service. The Panel, therefore, recommends that the provisions of law which require the referral of these cases to the Department of Justice be modified to provide that action be completed by the Department of Justice within sixty days. ${ }^{14}$

Had Congress chosen to enact the panel's recommendation into law, it is doubtful that even under normal conditions the processing of cases could have been accomplished in this time. The FBI investigation alone required thirty to sixty days to complete and, considering the usual scope of these investigations, this represented a remarkable achievement.

As finally enacted, the Military Selective Service Act of 1967 entirely eliminated special appellate procedures for conscientious objector claimants. ${ }^{15}$ This action can be traced to the recommendations of the House Committee on Armed Services. As originally introduced in the Senate, the bill to amend the Universal Military Training and Service Act ${ }^{16}$ would have left section $6(j)$ in its original form. As it later emerged from the House Committee, the special appeal procedures for conscientious objectors had been deleted. ${ }^{17}$ The report accompanying the bill explained the Committee's action in the following terms:

The Director of Selective Service advised the Committee on Armed Services that in his judgment this undue expansion of the provision of the law relating to conscientious objection could very easily result in a substantial increase in the number of unjustified appeals for exemption from military service based upon this provision of law.

This circumstance coupled with the Committee's awareness that the processing of conscientious objector appeals has resulted in delays exceeding two years, prompted the Committee to completely rewrite this provision of the law. ${ }^{18}$

14 Civilian advisory Panel on Military Manpower Procurement, Report to the Committee on ArMed Services of the House of Representatives, 90th Cong., 1st Sess. 14 (1967).

15 50 U.S.C. APP. $\S 456(j)$ (1964), as amended by P.L. 90-40, § I(7), 81 Stat. 104 (1967).

16 S. 1432, 90th Cong., Ist Sess. (1967).

17 H.R. REP. No. 267, 90th Cong., 1st Sess. 61 (1967).

18 Id. at 31 . 
A statement of the House-Senate conferees makes it equally clear that the action of Congress was directed at the elimination of what was regarded as an unnecessary delay in the processing of conscientious objector claims:

The Senate agreed that the referral on appeal of all conscientious objector cases to the Department of Justice had resulted in unnecessary delays in the processing of these cases without corresponding significant advantages. Therefore, the deletion of this referral requirement was accepted by the Senate. ${ }^{19}$

While it would perhaps be difficult to take issue with the conclusion that extensive delays in the processing of claims for conscientious objector status represent a potentially injurious element, the judgment that special appellate procedures of the type formerly authorized do not provide "significant advantages" is highly questionable. This article will endeavor to show that the elimination of the special appellate procedures will have an adverse effect on the fair administration of the conscientious objector exemption and encumber the process of judicial review.

Before turning to a consideration of the problems raised by the recent change in procedure, it may be helpful to consider briefly the nature of the substantive standard and the general administrative framework under which it must be applied.

\section{The Standard}

Two kinds of exemption are available under current law for the registrant who qualifies for conscientious objector status. ${ }^{20} \mathrm{~A}$ registrant may be classified 1-O,21 in which case he will be exempt from all military service but required for a period of two years to perform civilian work "contributing to the maintenance of the national health, safety or interest." ${ }^{22}$ Alternatively, if the registrant's opposition is limited to the "taking [of] life or active participation in mortal combat,"23 he will be designated $1-\mathrm{A}-\mathrm{O},{ }^{24}$ and will serve in the armed forces without taking part in combatant training and duty.

Eligibility for both forms of exemption is controlled by section $6(j)$ of the Military Selective Service Act of 1967, which provides that:

\footnotetext{
19 H.R. REP. No. 346, 90th Cong., Ist Sess. 15 (1967) (emphasis added).

2050 U.S.G. APP. $\S 456(\mathrm{j})$ (1964), as amended by P.L. 90-40, § 1(7), 81 Stat. 104 (1967).

2132 C.F.R. § 1622.14 (1968).

2250 U.S.C. APr. § 456(j) (1964), as amended by P.L. 90-40, § 1(7), 81 Stat. 104 (1967).

23 United States v. Moore, 217 F.2d 428, 433 (7th Cir. 1954), rev'd on other grounds, 348 U.S. 966 (1955).

2432 C.F.R. § 1622.11 (1968).
} 
Nothing contained in this title shall be construed to require any person to be subject to combatant training and service in the armed forces of the United States who, by religious training and belief, is conscientiously opposed to participation in war in any form. As used in this subsection, the term "religious training and belief" does not include essentially political, sociological, or philosophical views, or a merely personal moral code. ${ }^{25}$

In order to be eligible under this standard the registrant must meet three separate criteria. First, his objection must be grounded on "religious training and belief." Second, the objection must be sincere. Third, the objection must not be confined to any particular war, but must extend to "war in any form." While a detailed analysis of these criteria is beyond the scope of this article, a brief discussion of them will aid in evaluating the appropriateness of the procedures utilized in their application.

\section{A. Religious Training and Belief}

There are formidable difficulties in interpreting and applying the statutory limitation of exemption to those whose opposition is based on "religious training and belief." As Professor Mansfield has appropriately noted, these terms "are without any clear meaning in either legal or non-legal usage .... Although there may be a settled core meaning, so that certain instances clearly would fall within the signification of these terms, there is not even the beginning of general agreement as to their full reach or outer boundaries." ${ }^{26}$ In whatever manner a more orthodox society may have defined "religious training" and "religious belief," any "earlier consensus as to the meaning of these terms has suffered a progressive disintegration." 27 A growing number of claims grounded on beliefs less clearly identifiable with formal doctrines of established churches have inevitably resulted in unusual demands on the agencies charged with the administration of this exemption.

In United States $v$. Seeger ${ }^{28}$ the Supreme Court attempted to bring some definition into this nebulous area. The Court ruled that by defining "religious training and belief" in terms of a "Supreme Being" rather than "God," Congress intended the exemption to embrace the widest possible spectrum of religious belief. ${ }^{29}$ It construed the test for

2550 U.S.C. APP. § 456(j) (1964), as amended by P.L. 90-40, § I(7), 81 Stat. 104 (1967).

26 Mansfield, Conscientious Objection-1964 Term, in ReLrgron AND THE PUBLIC ORDER 12 (D. Giannella ed. 1965) [hereinafter cited as Mansfield].

27 Id.

28380 U.S. 163 (1965).

20 The statute at this time defined "religious training and belief" as "belief in a 
"religious training and belief" to be "whether a given belief that is sincere and meaningful occupies a place in the life of the possessor parallel to that filled by the orthodox belief in God of one who clearly qualifies for the exemption."30

The deletion of "Supreme Being" from the Military Selective Service Act of $1967^{31}$ abrogated any clarification which Seeger brought to the law. The legislative history makes it clear that the change was specifically designed to narrow the Seeger standard..$^{32}$ The result is that the test, while "narrowed," is now totally undefined. And the underlying constitutional issues are wholly unresolved. ${ }^{33}$ Until these problems are settled at higher judicial levels, the primary burden of interpretation will fall on the agencies of the Selective Service System.

\section{B. Sincerity of Belief}

The disposition of a claim is greatly affected by the strength and conviction of the belief on which it is based. To be "conscientiously opposed" implies by definition that the objector in fact entertains the belief to which he has given expression. In determining sincerity, it is relevant to inquire into the consistency of the applicant's actions with his stated beliefs. ${ }^{34}$ The difficulty of making the necessary determination varies with the type of case. Assessment is fairly simple in the instance of a claimant who since childhood has been affiliated with a religious order whose doctrine prohibits military service. Here sincerity can be inferred from the registrant's general conformity to church practices. The non-affiliated objector, in contrast, presents greater problems, since objective facts from which sincerity can be inferred are less likely to be available. Here too, however, the claimant's demeanor and activities over an extended period of time are highly relevant. In the past this type of background information was largely provided by the

relation to a Supreme Being involving duties superior to those arising from any human relationship, but does not include essentially political, sociological, or philosophical views or a merely personal moral code." Universal Military Training and Service Act, ch. 625, $\S 6(j), 62$ Stat. 612 (1948).

30380 U.S. at 166.

3150 U.S.C. APP. \& 456(j) (1964), as amended by P.L. 90-40, \& 1(7), 81 Stat. 104 (1967).

32 H.R. Rep. No. 267, 90th Cong., Ist Sess. 31 (1967); 113 Cong. REc. 6285 (daily ed. May 25, 1967) (statement by Chairman Rivers); H.R. REP. No. 346, 90th Cong., 1st Sess. (1967).

33 See generally Mansfield at 59-61; Giannella, Religious Liberty, Nonestablishment, and Doctrinal Development-Part I. The Religious Liberty Guarantee, 80 HARv. L. REv. 1381, 1425-1431 (1967); Rabin, When is a Religious Belief Religious: United States $v$. Seeger and the Scope of Free Exercise, 51 CoRNell L.Q. 231 (1966); Brodie \& Southerland, Conscience, The Constitution, and The Supreme Court: The Riddle of United States $v$. Seeger, 1966 WIs. L. REv. 306.

34 Mansfield at 20. 
FBI report. The elimination of this seemingly indispensable source of information leaves the board with little but the registrant's evidence. Faced with this situation, some boards may be tempted to deny claims disassociated from established religious beliefs because of a reluctance to grant an exemption based solely on the registrant's testimony.

\section{G. Participation in War in Any Form}

Section 6(j) requires that the claimant be "opposed to war in any form." This has been construed to mean that the registrant's opposition must be generalized to encompass all wars; one whose opposition is limited to a particular war is outside the statutory standard..$^{35}$ It should be noted that the claimant is not required to eschew the use of force in all situations, ${ }^{36}$ but only in the context of a war. Claimants whose objections did not extend to theocratic wars have argued, with some success, that "war" embraces a narrow category of conflicts. ${ }^{37}$

\section{Administrative Procedure for the Conscientious Objector Cllaimant}

\section{A. Initiation of the Conscientious Objector Claim}

The first opportunity a registrant has to assert a claim to conscientious objector status arises when he completes SSS Form 100, the classification questionnaire, which is sent to him by the local board shortly after his registration at the age of eighteen..$^{38}$ The form contains the following statement:

I claim to be a conscientious objector by reason of my religious training and belief and therefore request the local board to furnish me a Special Form for Conscientious Objector (SSS Form No. 150). ${ }^{39}$

Although the registrant is given no other official notification of the existence of the exemption, he is in fact entitled to assert a claim to conscientious objector status at any time prior to induction ${ }^{40}$ by completing SSS Form 150.

35 United States v. Kurki, 255 F. Supp. 161, 165 (E.D. Wis. 1966), aff'd, 384 F.2d 905 (7th Cir. 1967), cert. denied, 390 U.S. 926 (1968).

36 Shepherd v. United States, 217 F.2d 942, 945 (9th Cir. 1954); Pitts v. United States, 217 F.2d 590, 592 (9th Cir. 1954); Hinkle v. United States, 216 F.2d 8 (9th Cir. 1954), cert. denied, 348 U.S. 970 (1955).

37 See, e.g., Sicurella v. United States, 348 U.S. 385 (1955) (the term "war" embraces "real shooting wars" rather than theocratic wars fought in the defense of "Kingdom interests").

38 Rabin, supra note 7, 1967 WIs. L. REv. at 644 \& n.1.

39 SSS Form 100, Series VII (Sept. I5, 1966).

40 United States v. Stafford, 389 F.2d 215 (2d Cir. 1968); but cf. cases cited note 60 infra. 
SSS Form 150 is a five-part questionnaire. The first series of questions asks the registrant whether he is claiming exemption from all military service (1-O) or is limiting his claim to an exemption from combatant service (I-A-O). ${ }^{41}$ The second series concerns the registrant's religious training and belief. It consists of seven questions, requiring the registrant to state categorically whether or not be believes in a Supreme Being,42 to "describe the nature" of his belief and his idea of the relation of a Supreme Being to man-made law,"3 and to indicate "how, when, and from what source" he "received the training and acquired the belief which is the basis of [his] claim." 44 Later questions ask the registrant "under what circumstances, if any, [he] believe[s] in the use of force" 45 and what "actions and behavior" in his life demonstrate the "consistency and depth of [his] religious convictions." 46

A third series inquires into the registrant's background, his education, employment, places of residence and the religious affiliations of his parents. ${ }^{47}$ The fourth series consists in part of questions which focus on the registrant's religious affiliations. ${ }^{48}$ The final section requires the registrant to list persons "who could supply information as to the sincerity of [his] professed convictions." 49

One jurisdiction employs a supplementary questionnaire for a registrant "claiming to be a conscientious objector and/or minister of religion." ${ }^{50}$ Most of the questions on this form are aimed specifically at Jehovah's Witnesses, and attempt to determine whether the applicant really qualifies as a minister or can only claim conscientious objector status. ${ }^{51}$

In addition to these forms, the registrant may submit supplementary written information when his claim is being considered-for instance, letters attesting to good character and sincerity, or printed material from his religious sect describing its opposition to war.

\footnotetext{
41 SSS Form 150, Series I (Feb. 9, 1959).

42 Id., Series II, question 1.

$43 I d$., question 2.

44 Id., question 3.

$45 I d$. , question 5.

46 Id., questions 6 \& 7.

47 Id., Series III.

48 Id., Series IV, question 2.

$49 \mathrm{Id}$., Series $\mathrm{V}$.

50 SSS-N.Y. City Form 54.

61 There are 10 questions, 3 addressed to employment, 2 to the ministry, 3 to Jehovah's Witnesses specifically, and 2 to conscientious objection ("Under what circumstances [do] you believe in the use of force," and "Explain the basis of your claim of conscientious objection.") Id.
} 
B. Processing of the Application at the Local Board Level

1. Decision on the Written Record. The local board can take one of three actions on the application.

It can place the registrant into either of the two conscientious objector classes, which may mean that a registrant who has applied for total exemption from military service (1-O) will be exempted only from combatant service (1-A-O).

It can deny the application on the merits, in which case the registrant will be placed in class $1-A$, but is still entitled to appeal the decision through the proper channels.

It can refuse to consider the claim on one of three possible grounds: (a) that the registrant is qualified for a lower classification; (b) that the registrant has been previously classified by the local board and the information now presented is not sufficient to justify reopening the classification; or (c) that the claim was raised after an induction order had been sent.

The first ground is an outgrowth of section 1623.2 of the regulations which requires that the registrant be placed in the lowest class for which he is eligible. ${ }^{52}$ Since $1-\mathrm{A}-\mathrm{O}$ and $1-\mathrm{O}$ are the highest classes below $1-A,{ }^{53}$ the local board may postpone or completely avoid considering the claim of a registrant who qualifies for another deferment or exemption.

The local board may also refuse to reopen on the ground that "the information accompanying [a claim] fails to present any facts in addition to those considered when the registrant was [previously] classified or, even if new facts are presented, the local board is of the opinion that such facts, if true, would not justify a change in such registrant's classification." 54 But a board may not refuse to reopen and consider a claim on the merits where the registrant has presented facts which place him prima facie in the classification he is seeking. ${ }^{55}$

If the board refuses to reopen, the registrant is informed of this by letter. ${ }^{56}$ No further formal remedies are available, ${ }^{57}$ although the registrant may be able to persuade the state or national director to instruct the local board to reopen his case.

5232 C.F.R. § 1623.2 (1968).

53 Id.

54 Id. § 1625.4 .

65 Miller v. United States, 388 F.2d 979, 975-976 (9th Cir. 1967); United States v. Walsh, 279 F. Supp. 115, 120 (D. Mass. 1968).

5632 C.F.R. \& 1625.4 (1968).

57 United States v. Beaver, 309 F.2d 273, 277 (4th Cir. 1962), cert. denied, 371 U.S. 951, (1963); Stain v. United States, 235 F.2d 339, 342 n.7 (9th Cir. 1956); Klubnikin v. United 
The final ground, that the conscientious objector claim was first made after the notice of induction had been sent, ${ }^{58}$ is ostensibly authorized by the regulation which provides that "the classification of a registrant shall not be reopened after the local board has mailed to such registrant an Order to Report for Induction . . . unless the local board first specifically finds there has been a change in the registrant's status resulting from circumstances over which the registrant had no control."'69

Five circuits have held that as a consequence of this provision local boards need not entertain any claim for conscientious objector status that is first asserted after an induction order has been sent. ${ }^{60}$ This result has been rationalized in terms of the necessity for preventing undue disruption of the selective service machinery. Some courts have also reasoned that the status of conscientious objector is the product of volition, and therefore not a change beyond the registrant's control. ${ }^{61}$

The Second Circuit, on the other hand, held in United States $v$. Gearey $^{62}$ that the application of a registrant seeking conscientious objector status must be considered by the local board even after an induction notice has been sent to him. The local board must determine the point in time at which the applicant's beliefs matured. If it finds that they existed before the induction notice was sent, the local board need not reopen the registrant's case. But if the board concludes that the registrant's beliefs ripened only after his induction notice was received, then his case must be reopened. The court expressed the view that "the realization that induction is pending, and that he may soon be asked to take another's life, may cause a young man finally to crystallize and articulate his once vague sentiments." 63 The change in the registrant's status subsequent to receipt of his induction notice was thus viewed as resulting from circumstances over which the registrant

States, 227 F.2d 87 (9th Cir. 1955), cert. denied, 350 U.S. 975 (1956); Warren v. Abernathy, 198 F.2d 622 (10th Cir. 1952).

58 See, e.g., United States v. Gearey, 368 F.2d 144 (2d Cir. 1966), cert. denied, 389 U.S. 959 (1967); United States v. Taylor, 351 F.2d 228 (6th Cir. 1965); Porter v. United States, 334 F.2d 792 (7th Cir. 1964); Keene v. United States, 266 F.2d 378 (10th Cir. 1959).

5932 C.F.R. § 1625.2 (1968).

60 Parrott v. United States, 370 F.2d 388, 394, 396 (9th Cir. 1966), cert. denied, 387 U.S. 908 (1967); United States v. Al-Majied Muhammed, 364 F.2d 223 (4th Cir. 1966); United States v. Taylor, 351 F.2d 228 (6th Cir. 1965); Porter v. United States, 334 F.2d 792 (7th Cir. 1964); United States v. Beaver, 309 F.2d 273, 276 (4th Cir. 1962), cert. denied, 371 U.S. 951 (1963). See Keene v. United States, 266 F.2d 378, 383-84 (10th Cir. 1959), for a statement of the rationale mentioned in the text.

61 See Keene v. United States, 266 F.2d 378 (10th Gir. 1959); Parrott v. United States, 370 F.2d 388 (9th Cir. 1966).

62368 F.2d 144 (2d Cir. 1966).

$63 \mathrm{Id}$. at 150 . 
had no control. ${ }^{64}$ The court insisted that if the regulation were held to prevent consideration of any claim arising after the induction notice had been sent, it would improperly limit the statutory exemption Congress granted to all conscientious objectors to those who were objectors before receiving the notice.

2. Personal Appearance. A registrant whose application for classification as a conscientious objector is denied on the merits is entitled to pursue his claim either by filing an administrative appeal or by having the matter in effect reconsidered by his local board after appearing before it in person. Where the registrant elects the latter course, his request for a personal appearance must reach the local board within thirty days of the mailing of the notice of classification. ${ }^{65}$

The registrant is notified by letter of the time and date set for the appearance. At the appearance the registrant may not be represented by counsel. ${ }^{66}$ Though this rule has been frequently criticized, ${ }^{67}$ it has with. stood repeated challenges in the courts. ${ }^{68}$

The personal appearance is closed to the public. It is the practice of local boards to admit only the registrant and such other witnesses as it may choose to hear. ${ }^{69}$ The Selective Service System takes the position that a closed hearing is required by section 1606.31 of the regulations. ${ }^{70}$ This section, however, merely provides that:

Except as provided by law or by regulations in this part, the records in a registrant's file and the information contained in such records shall be confidential. ${ }^{71}$

The wording suggests that this regulation was formulated to offer protection to the registrant. The section immediately following permits the registrant to authorize the release of any information contained in

64 Id. at 149. Judge J. Spencer Bell, dissenting in United States v. Beaver, 309 F.2d 273 (4th Cir. 1962), responded to the issue in the following terms: "I leave to the theologians the intriguing conclusion of both the Board and the Court that the registrant's change of status did not result from circumstances over which the registrant had no control." Id. at 278.

65 32 C.F.R. § 1624.1(a) (1968).

66 Id. $\S 1624.1(\mathrm{~b})$.

67 The Draft 317 (S. Tax ed. 1967); Comment, The Selective Service System: An Administrative Obstacle Course, 54 CalIF. L. REv. 2123, 2150 (1966); Comment, The Selective Service, 76 YALE L.J. 160, 186-87 (1966).

68 United States v. Sturgis, 342 F.2d 328 (3d Cir.), cert. denied, 382 U.S. 879 (1965); United States v. Wierzchucki, 248 F. Supp. 788 (W.D. Wis. 1965). See also United States v. Capson, 347 F.2d 959 (10th Cir.), cert. denied, 382 U.S. 911 (1965); Imboden v. United States, 194 F.2d 508 (6th Cir.), cert. denied, 343 U.S. 957 (1952).

6932 C.F.R. § 1624.I(b) (1968); Uffelman v. United States, 230 F.2d 297 (9th Gir. 1956).

70 Interviews by the author with staff officials attached to the state headquarters of various jurisdictions.

7132 C.F.R. § 1606.31 (1968). 
his file..$^{72}$ If the policy of holding closed hearings is an extension of the same concern for the rights of the registrant, waiver should be permitted here also. But the rule is absolute, suggesting that the practice is in fact designed to serve the convenience of the Selective Service System.

The length of the personal appearance varies, but it is not unusual for local boards to schedule appearances every ten minutes. The procedures employed at these hearings also vary greatly, though at least one state headquarters has endeavored to establish a measure of standardization throughout its jurisdiction by providing its local boards with a list of questions that may be asked of the conscientious objector claimant. ${ }^{73}$

72 Id. § $1606.32(a)(1)$.

73 "SUGGESTED QUESTIONS TO BE PRESENTED TO CLAIMANTS OF CONSCIENTIOUS OBJECTION.

"1. Are you a practicing member of a religious group? Please describe: (a) your attendance at meetings, how many times a month[;] (b) the tenents [sic] of this group[;] (c) when did you join this group?

“2. What do you understand by the term 'Supreme Being'?

“3. Suppose the Supreme Being does not exist: on what premises would you base your Conscientious Objection to military service in the Armed Forces[?]

"4. Is your belief a religious belief or is it based on 'humanism' by which I would understand a respect for human rights, with or without benefits or deity?

“5. Is this belief which brought about your claim for Conscientious Objection your conscience or something greater than yourself?

"6. Do you believe any sanctions are imposed as a result of disobeying your conscience, if so from whence are the sanctions derived and what is the nature of such sanctions? "7. If the sanctions result in physical or psychological discomfort or pain, explain why the surgeons and doctors of the Armed Forces could not treat same as they would for soldiers who suffer such pain?

"8. If there are no resulting sanctions, what prevents you from serving in the Armed Forces, contrary to the dictates of your conscience?

"9. Do you believe that man survives after death in some form? If so, what do you understand by survival[;] immortality, or shadowy existence?

"10. Do you feel an obligation to state the truth to the inquiries concerning your claim for Conscientious Objection in cooperation with your Local Board?

"11. Is your purpose in claiming Conscientious Objection partly to demonstrate your disagreement with the Government's policies, if so, to what extent?

"12. Ave you compelled not to participate in any way, shape or form with the war effort?

"13. If so, how do you explain your payment of taxes?

"14. If this country were attacked without any justification whatsoever by an armed unprovoked aggression [sic] intent upon subjecting his will upon us, would you comply to a call to armed [sic] issued by the President for the defense of the people of this country? Please answer merely, yes or no.

"15. If your friends, neighbors and family, many of whom may not share your sentiments toward military defense, were subjected to an armed unprovoked aggression of another state, would you permit their lives to be sacrificed along with yourself so that you could exercise your objections to war by an onslaught similar to that of the Nazi's [sic], assuming all attempts to [sic] a peaceful settlement failed?

"16. If you believe in the defense of yourself and your immediate family against an unjustified attack, could you not extend this defensive attitude to defending your im- 
Local boards have made little use of their power to subpoena witnesses and evidence. ${ }^{74}$ This is perhaps best explained by extensive fact gathering which occurs at the appellate level as a matter of course and the general tendency of local boards under the old scheme to relinquish the disposition of cases raising any measure of doubt to the appellate level. ${ }^{75}$ Boards are under no obligation to preserve a record of the testimony offered at the personal appearance. For the most part the only entry relating to the personal appearance has been a notation of the decision reached. A minority of boards have, however, as a matter of voluntary practice, prepared brief summaries of the testimony for entry into the registrant's file. ${ }^{76}$

The registrant is notified of the board's decision by the mailing of SSS Form 110 which designates the class into which he has been placed; he receives no explanation. ${ }^{77} \mathrm{He}$ is also notified that he has thirty days from the time the form was mailed in which to appeal an adverse decision. $^{78}$

\section{Procedure on Appeal}

Upon receipt of notification by the registrant of his intention to appeal the decision, the local board normally forwards the registrant's file to the appeal board for that area. ${ }^{79}$ If, however, a registrant residing outside that appeal board's jurisdiction requests that his appeal be considered by the board of the jurisdiction where he resides, his file is sent to the state director's office and forwarded from there to the appropriate appeal board. ${ }^{80}$ Although it is not required by the regula-

mediate community and then go one step further and extend it to the defense of your country of [sic] an unprovoked, inhuman attack.

"17. Are your views based on religious training, if so state what religion and what training you underwent.

"18. Are these views founded upon reason and experience alone? Would your views be better described as philosophical beliefs or your own personal moral code rather than religious?

"19. Do you believe that certitude is possible in life?

"20. If not, how can you be certain of your Conscientious Objection?

"21. If your belief is based on other than a relationship to a Supreme Being, explain what it is based upon. How does it involve duties superior to that of serving in the Armed Forces in common defense of your fellow man at the insistance [sic] of your Government?

"22. Would you have participated in the so called 'Berlin Airlift' enacted during the Truman Administration to bring aid to the people of Berlin, by the use of the military?" 7432 C.F.R. § 1621.15 (1968).

75 Rabin, supra note 7, 1967 WIs. L. REv. at 650-51.

76 See, e.g., Gonzales v. United States, 364 U.S. 59 (1960); Witmer v. United States, 348 U.S. 375 (1955); United States v. Gearey, 379 F.2d 915 (2d Gir. 1967); United States v. Stepler, 258 F.2d 310 (3d Cir. 1958); Shepherd v. United States, 217 F.2d 942 (9th Cir. 1954).

7732 C.F.R. § 1624.2(d) (1968).

78 Id. $\$ 1624.2(\mathrm{c})(1)$.

$79 \mathrm{Id}$. $\$ 1626.13$.

80 Id. § $1626.13(\mathrm{~b})$. 
tions, the state headquarters in some jurisdictions prepare a summary of the file, which is forwarded to the appeal board with the file. ${ }^{81}$

A typical summary is approximately two typewritten pages in length, consisting of six sections: Education, Dependents, Physical Condition, Occupation, Religion, and Other Pertinent Information. The information on religion is a mixture of objective facts abstracted from the SSS Form 150 and, more significantly, a characterization of the nature of the registrant's belief. Thus, a form may contain the notation, "belief based on convictions of a philosophic or moral nature," or, alternatively, "belief based on convictions of a religious nature."

Any determination of the extent to which these characterizations may influence the disposition of cases by appeal boards must await the accumulation of cases processed under these procedures. It seems clear, however, that any appreciable reliance would have the effect of removing decision-making to state headquarters in somewhat the same fashion as, under former procedures, the decisions were in effect made by the Department of Justice. ${ }^{82}$ Since the registrant does not see this summary before it goes to the appeal board, and therefore cannot reply to any detrimental inferences the summary may make from his file, this practice seems clearly prejudicial to a fair consideration of his case. ${ }^{83}$

The registrant is not permitted to appear in person before the appeal board, but he "may attach to his appeal a statement specifying the matters in which he believes the local board erred, may direct attention to any information in the registrant's file which he believes the local board has failed to consider or to give sufficient weight, and may set out in full any information which was offered to the local board and which the local board failed or refused to include in the registrant's file." ${ }^{4}$ It has been held that the appeal board procedure is de novo, unaffected by local board proceedings. ${ }^{85}$ It is difficult to reconcile this with the weight some courts have been willing to assign to the registrant's demeanor in connection with the element of sincerity. ${ }^{86}$

81 Interviews by the author with two state directors.

82 Rabin, supra note 7, 1967 Wis. L. REv, at 668-669.

83 The prejudice to the registrant in this situation is similar to that under the former procedure when the registrant was deprived of knowledge of the contents of the Department of Justice recommendations. In Gonzales v. United States, 348 U.S. 407 (1955), this denial of an "opportunity to file a reply" was deemed to contravene the statutory requirement of procedures that are " 'fair and just' in their operation." Id. at 417.

84 32 C.F.R. \& 1626.12 (1968).

85 "It is universally held that the Appeal Board considers matters of classification de novo and its classification is one of first instance, not a mere affirmance or reversal of the Local Board." DeRemer v. United States, 340 F.2d 712, 719 (8th Cir. 1965).

86 See, e.g., Witmer v. United States, 348 U.S. 375, 382 (1955); United States v. Corliss, 280 F.2d 808 (2d Cir.), cert. denied, 364 U.S. 884 (1960). 
Generally, appeal boards do not write opinions, but simply classify the registrant and record the yes and no votes. ${ }^{87}$ One jurisdiction, however, has suggested that when appeal boards deny a claim they "should be able to point to one or more . . . critical elements as the basis in fact" for the denial. ${ }^{88}$ This is presumably a result of the elimina-

8732 C.F.R. \& 1626.27 (1968).

88 The following memorandum, dated October 10, 1967, was sent by the Director of the Selective Service of the City of New York to all appeal boards in that area:

\section{MEMORANDUM TO: ALL APPEAL BOARD MEMBERS SUBJECT : CONSCIENTIOUS OBJEGTORS (1-A-O and 1-O)}

1. It is well known that claims of Conscientious Objection must be most carefully considered.

2. A person who is denied a III-A, II-S, etc, will normally report and submit to induction when ordered. But a denial of a 1-O claim will usually be decided in the courts, normally as a prosecution when the registrant fails to report or submit to induction.

3. The courts will not review the judgment of the Local Board or Appeal Board when there is a basis in fact for the denial of the claim contained in the Cover Sheet. Therefore, an Appeal Board when it reaches a conclusion to deny a claim should be able to point to one or more of the following critical elements as the basis in fact:

a) Registrant does not sincerely hold the beliefs he sets forth. In this regard, the comments of the Local Board regarding his demeanor, manner in answering questions, etc., and their own feelings on his sincerity may be used, along with the timeliness of his claim and the manner in which he sets it forth.

b) The registrant is not opposed to war in all forms including one purely defensive in nature. In this regard the board should be able to find that the registrant would reply in the negative to the following, "If this country were invaded by a strong, powerful nation which was being popularly led by an irresponsible irrational leader intent upon subjecting the people of the United States to his will, and with whom all conceivable methods of peacefully negotiating the situation had failed, would he, the registrant, comply with a call to arms issued by the President of his Country"?

c) The registrant is not opposed to war based upon his religious training and belief (as defined by U.S. v. Seeger) but is motivated purely out of political, sociological, racial or economic considerations; or disavowing religious training and belief he bases his objection to war on a purely personal moral code, or philosophical view.

Moreover, the boards may not deny a claim on mere suspicion. If they merely suspect the registrant's sincerity or opposition to war in all forms, without a basis in fact, they may return the file to the Local Board and request more information in the specific area in which suspicion is raised and, if desired, frame a question they wish the registrant to answer.

4. It should also be pointed out that the Local Boards or Appeal Boards have no jurisdiction to question the validity of a person's beliefs. However, if his beliefs in the common sense of the word are so ridiculous, as to be incredible, the claim may well be denied for lack of sincerity.

5. Normally, the members of the traditional pacifict religions, such as, Mennonites, Quakers, Amish, Jehovah's Witnesses, Assembly of God, or Pentecostal (the latter often merely request $1-\mathrm{A}-\mathrm{O}$, as do the Seventh Day Adventists), set forth a prima facie case for 1.0 and should be granted their claim for 1-O, unless the prima-facie aspect is outweighed by a manifested lack of sincerity.

6. This memo is deemed necessary in view of the new provisions of the Military Selective Service Act of 1967, which eliminated the Justice Department's hearing which in most instances supplied the Appeal Board with a basis in fact for its decision.

7. Hereafter, the Appeal Boards will have to depend entirely upon the Local Boards for providing the necessary basis in fact for either granting or denying a claim for Conscientious Objection. If, in the opinion of the Appeal Board, there 
tion of Justice Department participation and the consequent need to build a record within the Selective Service System. ${ }^{89}$

The registrant is informed of the appeal board decision by receipt of a notice of classification on which the yes and no vote is recorded.90 If the appeal board vote is not unanimous, the registrant can by right appeal to the President's board, ${ }^{91}$ the final level of administrative review. The state director or national director may also prosecute an appeal to the President's board at their discretion.92 The board then makes a classification after reviewing the registrant's entire file. There is no personal appearance and the board does not write opinions. The registrant learns of its decision by receipt of a notice of classification including a statement that this latest action is "by President."93

Finally, it should be noted that a case may be reconsidered at the local or appeal level. The local board may reopen the classification on the registrant's or its own motion if new information is presented which may justify a change in classification. ${ }^{94}$ It must reopen the classification on the request of the state or national director..$^{95}$ The appeal board must reopen the classification on the request of the state or national director, and the government appeal agent can recommend that the state director make such a request or that he appeal the case to the President's board. ${ }^{96}$

is no basis in fact to make a decision, the matter will be returned to the Local Board for further information. If desired, the Appeal Boards may request the Government Appeal Agents to obtain the necessary information. Of course, this added information must be first reviewed by the Local Board before returning the file to the Appeal Board.

8. One further point that merits concern, is that generally the criteria for 1-0 are identical with the criteria for 1-A-O, the only difference being in the type of relief sought or requested by the registrant. Too often it has been found that boards in the spirit of conciliation or compromise grant a 1-A-O when the request was for a 1-O. This type of bargaining would be fatal to an induction order. If the registrant does not qualify for a Conscientious Objector classification, he should receive neither $1-\mathrm{A}-\mathrm{O}$ or $1-\mathrm{O}$.

9. This memorandum is prepared for the Appeal Boards but will be distributed to the Local Boards so that they may be aware of the information required by the Appeal Boards and assist in obtaining same. Also, the boards will then be aware of the fact that the Appeal Boards no longer have the exhausting [sic] investigative proceedings of the Department of Justice available to them but must decide these cases in the same fashion and upon the same information as used by the Local Boards in making their decisions.

89 See Witmer v. United States, 348 U.S. 375 (1955); United States v. Washington, 392 F.2d 37, 39 (6th Cir. 1968).

9032 C.F.R. $\$ 1626.31$ (a) (1968).

91 Id. § 1627.3.

92 Id. \& 1627.1(a).

93 SSS Form 110 (May 25, 1967). See 32 C.F.R. § 1627.7 (1968).

94 Id. § 1625.2.

95 Id. \& 1625.3(a).

06 Id. \& 1626.61. 


\section{JUdicial REVIEW}

\section{A. Methods of Judicial Review}

There are two recognized methods by which the denial of a claim for conscientious objector status at the administrative level may be brought before the courts for review. The registrant may resist induction and allege improper classification as a defense in the criminal prosecution which will normally follow. ${ }^{97}$ Alternatively, he may submit to induction and challenge the induction order and underlying classification by habeas corpus. ${ }^{98}$ In other words, habeas corpus review is available only if the registrant has submitted to formal induction and is a member of the armed services.9.$^{90}$ The scope of review under these alternate methods is, at least in theory, ${ }^{100}$ identical.

Either method of obtaining review is available only if all administrative remedies have been exhausted by the registrant. Review by habeas corpus, therefore, can only be obtained if the registrant has taken advantage of all his appeal rights within the system before being inducted. ${ }^{101}$ In a criminal prosecution the registrant must not only have utilized all available appeal procedures but also have physically reported for induction before refusing to be formally inducted. ${ }^{102}$

97 The 1967 Act gives express recognition to this method of review. See text at note 105 infra. The availability of this mode of review was first established on the basis of less explicit congressional authority. In Estep v. United States, 327 U.S. 114 (1946), the Supreme Court held that, despite a provision of the Selective Training and Service Act of 1940 which made the decisions of local boards "final," judicial review of classification decisions could be had in the context of a criminal prosecution if the registrant had exhausted his administrative remedies.

08 Estep v. United States, 327 U.S. 114, 123-24 (1946).

99 Ex Parte Fabiana, 105 F. Supp. 139 (E.D. Pa. 1952), represents an exception to this rule. The Court in that case granted a writ despite the fact that the registrant had not been inducted into the armed services. The Court reasoned that having received a notice to report for induction the registrant was in constructive custody of the government. Although the Fabiana case was not appealed, the circuit courts have rejected the constructive custody concept in both subsequent and prior cases. Biron v. Collins, 145 F.2d 758 (5th Cir. 1944); Lynch v. Hershey, 208 F.2d 523 (D.C. Cir. 1953), cert. denied, 347 U.S. 917 (1954). See Note, Habeas Corpus and Judicial Review of Draft Classifications, 28 IND. L.J. 244 (1953).

100 While the Supreme Court has never addressed itself expressly to this issue, the general thrust of several opinions supports the conclusion. See Cox v. United States, 332 U.S. 442, 449 (1947); Eagles v. United States ex rel Samuels, 329 U.S. 304, 312 (1946). See generally United States ex rel. Coltman v. Bullock, 110 F. Supp. 126, 145 (N.D. Ill. 1953). 101 See, e.g., Wyman v. LaRose, 223 F.2d 849 (9th Cir. 1955).

102 See, e.g., Daniels v. United States, 372 F.2d 407 (9th Cir. 1967); Moore v. United States, 302 F.2d 929 (9th Cir. 1962); Williams v. United States, 203 F.2d 85 (9th Cir.), cert. denied, 345 U.S. 1003 (1953). 
Five months prior to enactment of the 1967 Act, the Second Circuit recognized another method of judicial review, by granting injunctive relief to two students who had been stripped of their student deferments and reclassified 1-A following their participation in a war protest demonstration at the offices of a local Selective Service board. ${ }^{103}$ The court held that classification decisions may be reviewed before the registrant has exhausted his administrative remedies when judicial action is necessary to avert a "threat to First Amendment rights" of "immediate and irreparable consequence" to the registrant and others similarly situated. ${ }^{104}$

Congress attempted to nullify even this narrow exception, presumably extending only to cases having free speech and association implications, in the 1967 Act. The new legislation provides that:

No judicial review shall be made of the classification or processing of any registrants by local boards, appeal boards, or the President, except as a defense to a criminal prosecution instituted under section 12 of [the Act], after the registrant has responded either affirmatively or negatively to an order to report for induction, or for civilian work in the case of a registrant determined to be opposed to participation in war in any form..$^{105}$

The precise effect of the congressional action is yet to be determined; the Supreme Court has granted certiorari in a case raising the question whether this provision places "an unconstitutionally heavy burden on the right to judicial review."100

103 Wolff v. Selective Serv. Local Bd. No. 16, 372 F.2d 817 (2d Cir. 1967). For an analysis of this case, see Note, Judicial Review of Selective Service Action: A Need for Reform, 56 CALIF. L. REv. 448 (1968); Layton \& Fine, The Draft and Exhaustion of Administrative Remedies, 56 Geo. L.J. 315, 328 (1967).

$104372 \mathrm{~F} .2 \mathrm{~d}$ at 820 .

10550 U.S.C. APP. $\S 460(\mathrm{~b})(3)$ (1964), as amended by P.L. 90-40, § I(8)(c), 81 Stat. 104 (1967). See H.R. REP. No. 267, 90th Cong., 1st Sess. 7 (1967). Congress has also indicated a desire to have judicial review of Selective Service cases accomplished in the shortest possible time. District as well as appellate courts are specifically directed by the new law to give precedence to the hearing of cases arising under the Act. 50 U.S.C. APP. $\S 462$ (1964), as amended by P.I. 90-40, § 1(11)(a), 81 Stat. 105 (1967).

106 Oestereich v. Selective Serv. Local Bd. No. 11, 280 F. Supp. 78 (D. Wyo.), aff'd 390 F.2d 100 (10th Cir.), cert. granted, 88 S. Ct. 1804 (1968). See 36 U.S.L.W. 3437 (1968). Plaintiff in this case sought to enjoin his induction after he had been reclassified from 4-D (ministerial exemption) to $\mathrm{l}-\mathrm{A}$ for returning his registration certificate in protest against the Vietnam war. The district court dismissed the complaint, and the Tenth Circuit affirmed. After plaintiff petitioned the Supreme Court for certiorari, the Solicitor General filed a memorandum containing a suggestion of error and recommending remand. While he asserted that $\S 10(\mathrm{~b})(\mathfrak{3})$ of the 1967 Act prohibits judicial review of reclassification decisions prior to induction or criminal prosecution, the Solicitor General recognized an exception where the local board has acted contrary to statute in administratively termi- 
As has been noted, the scope of review under the two available forms is ostensibly identical. ${ }^{107}$ Review by habeas corpus provides the registrant with an opportunity to test the validity of a classification or its refusal without having to incur the risk of a criminal conviction. While it might therefore appear preferable, it is, in fact, entirely unsuited for the review of claims for conscientious objector status. In order to test the validity of his claim by habeas corpus, the registrant must submit to the very status which is the basis of his objection. For the committed objector this is hardly a viable option, ${ }^{108}$ and it is equally impractical from the tactical standpoint. The registrant's submission to induction may be taken by the courts as evidence of insincerity. They may assume that an objector whose convictions are sincere would elect the alternate method which does not in any way compromise his beliefs and involves the risk of criminal prosecution. While this sort of reasoning does not appear in the written decisions, the virtual absence of successful habeas corpus actions ${ }^{109}$ suggests that it has influenced the disposition of cases.

\section{B. Scope of Review}

1. Review for Sufficiency of the Evidence. The Military Selective Service Act of 1967 specifically provides that agency action may be set aside "only when there is no basis in fact for the classification." 110 Congress has thus expressly sanctioned the standard of review deemed controlling since 1946 when the Supreme Court was called upon to construe the provision of the Selective Training and Service Act of

nating an exemption granted by the statute. Memorandum for Respondents at 11-13, Oestereich v. United States, No. 1246, 1967 Term. See Kimball v. Selective Serv. Local Bd. No. 15, Civil No. 67-4733 (S.D.N.Y. Apr. 22, 1968). The Court nevertheless granted certiorari.

Since the conscientious objector status is also a statutory exemption, it could be argued that judicial review in a civil proceeding prior to a refusal of induction may lie, at least where there is no colorable basis for the denial of objector status.

107 See note 100 supra.

108 "It should be noted in passing, however, that this remedy may be quite illusory in many instances. . . Many persons with religious or conscientious scruples are unable to meet such a condition." Estep v. United States, 327 U.S. 114, 129-30 (1946) (Murphy, J. concurring). Similarly, in United States v. Freeman, 388 F.2d 246 (7th Cir. 1967), the court observed that a "sincere claimant for conscientious objector status cannot turn to the habeas corpus remedy because his religious belief prevents him from accepting induction under any circumstances." Id. at 248-49.

109 See generally Note, Judicial Review of Selective Service Board Classifications by Habeas Corpus, 10 GEO. WASH. L. REv. 827, 830 (1942); Tietz, Jehovah's Witnesses: Conscientious Objectors, 28 So. CAL. L. REv. 123, 134 (1955).

11050 U.S.C. APP. $\S 460($ b)(3) (1964), as amended by P.L. 90-40, § 1(8)(c), 81 Stat. 104 (1967). 
1940111 which declared that "decisions of such local boards shall be final." This language was found to reflect a congressional purpose-

not to give administrative action under this Act the customary scope of judicial review which obtains under other statutes. ... [T] he courts are not to weigh the evidence to determine whether the classification made by the local boards was justified. The decisions of the local boards made in conformity with the regulations are final even though they may be erroneous. The question of jurisdiction of the local board is reached only if there is no basis in fact for the classification which it gave the registrant. ${ }^{112}$

This construction rested on the rationale that agency action entirely devoid of factual support is tantamount to a defect in jurisdiction. ${ }^{113}$ Since this class of defect would ultimately provide the basis for relief in a habeas corpus proceeding, it would be anomalous, the Court reasoned, to preclude its interposition at the earlier criminal trial stage. ${ }^{114}$

What still remains obscure is the difference between the Estep "any basis in fact" standard and the more conventional "substantial evidence" test required by the Administrative Procedure Act. ${ }^{115}$ The decisions establish that the former is supposed to require more restrictive review with greater weight being assigned to the findings of agencies of the Selective Service System. ${ }^{116}$ It is extremely difficult to judge the extent to which these doctrinal differences have found distinct application in judicial action. One commentator has concluded:

For every decision which apparently applies a substantial evidence test to the Selective Service proceedings, a decision can be found which faithfully adheres to the narrower scope of review implicit in the basis in fact test. And, occasionally, a

111 Ch. $720, \S 10(2), 54$ Stat. 893.

112 Estep v. United States, 327 U.S. 114, 122-23 (1946).

113 Id. See generally Hart, The Power of Congress to Limit the Jurisdiction of Federal Courts: An Exercise in Dialectic, 66 HARv. L. Rev. 1362, 1389-90 (1953).

114327 U.S. at 128-29 (Murphy, J. concurring). Only Justices Reed and Black joined Justice Douglas's opinion for the Court. Justices Murphy and Rutledge concurred specially on the ground that the scope of review Justice Douglas found by way of statutory interpretation was constitutionally required. Mr. Justice Rutledge expressed the view that it is beyond congressional powers to "make it a crime punishable by the federal judicial power to violate an administrative order without affording an adequate opportunity to show its constitutional invalidity ...." Id. at 133 .

1155 U.S.C. \$ 706 (Supp. II, 1967). See generally Jaffe, Judicial Review: "Substantial Evidence on the Whole Record," 64 HARv. L. REv. 1233 (1951); L. JAFFE, Judicial ConTROL OF ADMINISTRATIYE ACTION 600-04 (1965).

116 Blalock v. United States, 247 F.2d 615, 619 (4th Cir. 1957). 
court's detailed review of the factual record of the case can be mistaken for a weighing of the evidence. ${ }^{117}$

2. Review for Procedural Errors and Errors of Law. The validity of an induction order and its underlying classification may be challenged later on the ground that the denial resulted from the application of an erroneous statutory standard or that a procedural error was committed at some point of the administrative process.

As has been noted earlier, local and appeal boards have never been required to provide any explanation of classification decisions. Judicial interdiction of administrative errors of law would have been diffcult without the Department of Justice recommendation which, in setting forth the grounds for a denial, also disclosed the standard that had been applied. Reviewing courts assumed that, if appeal boards concurred in the Department's recommendation, they had also relied on its interpretation of the law. Accordingly, the application of an erroneous standard by the Department invalidated the classification.118 This result obtained even where the Department of Justice recommendation was bottomed on dual grounds, only one of which was legally defective. ${ }^{119}$ Here the refusal to sustain the administrative action probably represented nothing more than an effort to compensate for the narrowness of the reviewing standard on other issues. ${ }^{120}$

How reviewing courts will review for errors of law under current procedures is unclear at this time. Some of the problems that may be raised by the procedural changes of the 1967 Act which touch on this question will be considered in a subsequent section. ${ }^{121}$

While the registrant may challenge a classification decision on the grounds of procedural error, the defect must have been substantial and have resulted in prejudice to him. ${ }^{122}$ The question of who bears the burden of proving prejudice is not entirely settled. ${ }^{123}$ In Simmons

117 Comment, supra note 67, 54 CALIF. L. Rev. at 2140-41 (1966). See also Comment, Fairness and Due Process Under the Selective Service System, 114 U. PA. L. REv. 1014, 1020 (1966).

118 Sicurella v. United States, 348 U.S. 385 (1955); Shepherd v. United States, 217 F.2d 942 (9th Cir. 1954). Cf. United States v. Stepler, 258 F.2d 310 (3d Cir. 1958).

119 United States v. Jakobson, 325 F.2d 409 (2d Cir. 1963), aff'd sub nom. United States v. Seeger, 380 U.S. 163 (1965); United States v. Englander, 271 F. Supp. 182 (S.D.N.Y. 1967). Cf. Gatchell v. United States, 378 F.2d 287 (9th Cir. 1967).

120 This reasoning has generally not been made explicit. In a recent case, United States v. Freeman, 388 F.2d 246 (7th Cir. 1967), the court indicated that its close scrutiny for procedural irregularities was in part necessitated by the narrowness of the scope of review that controls the disposition of evidentiary questions. Id. at 249.

121 See Part V infra.

122 See Wyman v. LaRose, 223 F.2d 849 (9th Cir.), cert. denied, 350 U.S. 884 (1955).

123 United States v. Sturgis, 342 F.2d 328, 331 (3d Cir.), cert. denied, 382 U.S. 879 (1965). 
v. United States ${ }^{124}$ the Supreme Court distinguished between the "infringement of technical rights" and the deprivation of a "fundamental safeguard." In cases falling into the latter category, prejudice is presumed; where the denial is merely of a "technical right," the burden of proof is on the registrant. ${ }^{125}$

The circuits have not always agreed on which procedural errors are so fundamental as to obviate the need for proof of prejudice. The First Circuit, for instance, has held that failure to appoint advisors and post their names and addresses as required by regulations automatically contaminates the classification and induction order. ${ }^{126}$ Other circuits have concluded that this defect should not serve to invalidate the induction order and classification unless the registrant can offer proof of prejudice. ${ }^{127}$ These varying approaches reflect fundamental differences of opinion on the scope of review that should obtain in draft cases. The limited review that is available has undoubtedly caused some courts to overcompensate in their scrutiny of administrative procedures, ${ }^{128}$ but there is no lack of decisions that are less demanding of the Selective Service System. ${ }^{129}$

\section{Burden of Proof}

The burden of persuasion is on the registrant; he must tender suffcient evidence to show that he falls within the statutory standard..$^{130}$ Where an objective factual issue is involved, the Supreme Court has defined the circumstances in which a local board may deny a claim once the registrant has established prima facie that he is entitled to an exemption. Rejection of the claim can follow only upon the establishment of "some proof that is incompatible with the registrant's proof of

124348 U.S. 397 (1955).

$125 I d$. at 406.

126 Steele v. United States, 240 F.2d 142 (1st Cir. 1956).

127 United States v. Sturgis, 342 F.2d 328 ( $3 \mathrm{~d}$ Cir. 1965); Uffelman v. United States, 230 F.2d 297 (9th Cir. 1956).

128 See, e.g., United States v. Freeman, 388 F.2d 246 (7th Cir. 1967). Failure of local boards to inform the registrant whose application for conscientious objector status had been denied of his right of appeal constituted grounds for reversal of the conviction. This error was deemed prejudicial although registrant was awarded a 3-A (hardship) deferment after denial of his conscientious objector claim and he presumably could have reapplied for a 1-O classification immediately subsequent to revocation of the 3-A classification (before receipt of the order of induction).

129 See United States v. Corliss, 280 F.2d 808 (2d Cir.), cert. denied, 364 U.S. 884 (1960) (failure to apprise registrant of a letter sent to the appeal board by an unsolicited informant not grounds for reversal where prejudice was not specifically shown).

130 Wood v. United States, 373 F.2d 894, 897 (5th Cir.), vacated on other grounds, 389 U.S. 20 (1967). 
exemption."131 Thus, in Dickinson v. United States, the Supreme Court said: "The task of the courts ... [ [where the registrant has established a prima facie case] is to search the record for some affirmative evidence to support the local board's overt or implicit finding that a registrant has not painted a complete or accurate picture of his activities."132 Dickinson involved a claim of ministerial exemption. Since the registrant's evidence brought him within the statutory criteria and there was no "incompatible" evidence, the court held that the exemption must be granted. A similar result would follow if the only basis for the denial of a claim of conscientious objection rested on the disbelief of the local board in what the registrant claimed was an objective fact, such as that he regularly attended the services of his church. Such objective issues are rarely determinative, because usually "the ultimate question in conscientious objector cases is the sincerity of the registrant in objecting, on religious grounds, to participation in war in any form. In these cases, objective facts are relevant only insofar as they help in determining the sincerity of the registrant in his claimed belief, purely a subjective question." 133

Thus, every finding of sincerity or lack of sincerity rests on inferences drawn from the evidence before the board, and possibly on the demeanor of the claimant in his personal appearance before the board. The Supreme Court indicated in Witmer $v$. United States that the board may properly consider the registrant's demeanor. ${ }^{134}$ No court, however, has ever held that a claim can be denied because of the personal demeanor of the registrant before the board, where the only reasonable inferences from the objective facts support the registrant's sincerity. ${ }^{135}$ This is an important limitation on the power of the local

131 Dickinson v. United States, 346 U.S. 389,396 (1953).

132 Id. The dissenting opinion in Dickinson interprets the majority opinion as requiring that "[ $t]$ he Board must find and record affirmative evidence that [the registrant] has misrepresented his case." Id. at 399 (emphasis added). This interpretation of the majority opinion has not been generally adopted by other courts. See, e.g., Parrott v. United States, 370 F.2d 388 (9th Cir. 1966), cert. denied, 387 U.S. 908 (1967).

133 Witmer v. United States, 348 U.S. 375,381 (1955).

$134 \mathrm{Id}$. at 382 . The conclusion that demeanor may properly be taken into account is suggested by the Court's observation that, having found no "indication anywhere in the record that his demeanor appeared shifty or evasive or that his appearance was one of unreliability," the board was required to search for "objective facts" that might cast doubt on the registrant's sincerity. See also Parr v. United States, 272 F.2d 416 (9th Cir. 1959); Pitts v. United States, 217 F.2d 590 (9th Cir. 1954).

135 No case has been found where the registrant's demeanor provided the only basis in support of the administrative denial of the claim. One court has, however, suggested that demeanor alone would support a denial. United States v. Corliss, $280 \mathrm{~F} .2 \mathrm{~d} 808,814-815$ (2d Cir. 1960). Whether mere disbelief of the registrant's evidence would be sufficient is unclear. One court of appeals has suggested that "mere disbelief is not enough." Batterton v. United States, 260 F.2d 283, 237 (8th Cir. 1958). Another court has suggested by 
boards, particularly in view of the procedural changes effected by the 1967 Act. ${ }^{136}$

Previously the crucial decision-making power rested in the appeal board, ${ }^{137}$ which had before it a comprehensive FBI background report and a Department of Justice recommendation. This recommendation usually contained a narrative summary of the proceedings before a hearing officer who had heard the testimony of the registrant. ${ }^{138} \mathrm{Al}$ though the hearing officer occasionally commented on the registrant's demeanor in his report, the Department's recommendation rarely placed any emphasis on demeanor. ${ }^{139}$ Since the appeal board did not hear the registrant personally, demeanor was apparently not a significant factor in decisions under the prior law.

Under the present law, however, demeanor may come to play an important and perhaps exaggerated role in the decision-making process. The local board, whose decision now bears the greatest weight, will decide almost all cases solely on the basis of evidence presented by the registrant, and it is to be expected that such evidence will be consistent with his claim. The use of FBI background reports has been abandoned. Although the local boards have subpoena power and may also hear witnesses who voluntarily appear, an examination of actual case files reveals that subpoena power is almost never exercised and volunteer witnesses are rare. ${ }^{140}$ The paucity of information concerning the registrant available to the board, and the one-sided nature of the evidence before it, may tempt local boards to rest their judgments in-

way of dictum that "disbelief will suffice" provided that the "record . . . contain[s] some statement of this disbelief." United States v. Washington, 392 F.2d 37, 39 (6th Cir. 1968). Campbell v. United States, 221 F.2d 454 (4th Cir. 1955), probably comes closest to a holding that mere disbelief is sufficient, though even there the disbelief deemed permissible was against the background of a claim which was not filed "until military service became imminent." Id. at 457 .

136 See text at notes 156-57 infra.

137 Gonzales v. United States, 348 U.S. 407,413 (1955).

138 See, e.g., DeRemer v. United States, 340 F.2d 712, 714 (8th Cir. 1965).

139 This and several other findings contained in this article are based on an analysis of 95 cases of claims for conscientious objector status that were processed by the Department of Justice between January 1, 1966 and June 30, 1967. The names of 200 registrants whose files had been referred to the Department of Justice were drawn randomly by that Department from among approximately 1200 cases then pending. These names and the addresses of the registrants' local boards were given to the author who then wrote each registrant care of his local board requesting that the letters be forwarded to the registrant's last known address. Under 32 C.F.R. § 1606.41 (1968) local boards are required under specified conditions to forward mail addressed to the registrant. Of the 200 to whom letters were sent 103 replied; of this number 95 authorized access to their files and 8 refused authorization.

It should be emphasized that the conditions under which the study was conducted made it impossible to draw a sample which is predictably representative.

$140 \mathrm{Id}$. 
creasingly on the registrant's demeanor and personality traits. If "demeanor" includes the behavior of the registrant before the local board, this emphasis is clearly undesirable in the absence of objective facts which rebut the registrant's claims to sincerity. The registrant is being interrogated about deeply-held religious and moral beliefs; his five interrogators are possibly unsympathetic towards his claim for exemption, and by the exercise of their power may very well determine whether he will go to jail. Under these conditions it will not be surprising if the registrant appears nervous or antagonistic. Apparent evasiveness in answering questions may well stem from nervousness, lapse of memory, or attempts to be absolutely clear and honest in answering difficult questions reaching to borderlines of religious and moral issues. Many boards have standard questions which are essentially traps for the conscientious objector-"would you defend your wife if she were attacked?"141 Thus, while demeanor may properly be considered in connection with other factors, reliance on demeanor alone as a basis for denial of a claim should not be permitted.

It is necessary to look to the decided cases to see what other factors the local board may properly consider. Three factors are commonly sanctioned by the courts: contradictions in the registrant's evidence, lack of corroborating evidence, and belated submission of the claim.

Contradictions in the evidence presented by the registrant is probably the most frequently cited reason for sustaining the denial of a claim, and only in rare instances do the results appear to be less than soundly based. Statements that the applicant would work in a defense plant ${ }^{142}$ or make some other contribution to the "war effort,"143 or be-

141 See note 73 supra.

142 A registrant's expressed willingness to engage in defense production work or evidence that he has held such employment in the past is the most common "inconsistency" providing a basis in fact. DeRemer v. United States, 340 F.2d 712 (8th Cir. 1965); Keefer v. United States, 313 F.2d 773 (9th Cir. 1963); Blalock v. United States, 247 F.2d 615 (4th Cir. 1957); Meredith v. United States, 247 F.2d 622 (4th Cir. 1957); White v. United States, 215 F.2d 782 (9th Cir. 1954), cert. denied, 348 U.S. 970 (1955).

143 Witmer v. United States, 348 U.S. 375, 382 (1955). Other examples include: (I) Registrant, a Jehovah's Witness, engaged in rather heavy drinking and gambling and displayed "abusiveness and the exercise of physical violence toward his wife." United States v. Simmons, 213 F.2d 901 (7th Cir. 1954), rev'd on other grounds, 348 U.S. 397 (1955). (2) Registrant had advised his local board that "he had planned to be married in May or June but that it did not work out so he filed a claim as a conscientious objector." This statement coupled with the lateness of the registrant's application (filed after receipt of notice of induction) was deemed a sufficient basis in fact for the denial. Parrott v. United States, 370 F.2d 388 (9th Cir. 1966). (3) Registrant had applied for admission to a military college-academy less than one year before filing for conscientious objector status. United States v. Corliss, 280 F.2d 808, 817 (2d Cir. 1960). (4) Registrant had over a six year period made numerous requests for deferments, the claim had not been submitted until after receipt of the notice of induction, and registrant seemed at 
havior inconsistent with the doctrines of the registrant's church, such as drinking and gambling by a Jehovah's Witness, readily support an inference of lack of sincerity on the part of the registrant.

The second factor upon which some courts have relied to sustain a denial of objector status has been lack of evidence corroborating the registrant's claim, other than his own testimony and statements. ${ }^{144}$ In these cases, however, other factors have always supported the denial. It is reasonable to require the registrant asserting objector status to submit some independent corroboration, or an explanation of his failure to produce it, providing he has been notified after his appearance before the local board of the nature of the deficiency and the type of corroborating evidence needed to cure it. In the absence of this type of notice, a registrant can never be certain whether he has established a prima facie case until the culmination of judicial review. The prejudice here is similar to that which obtains where a registrant is not given the opportunity to rebut a negative recommendation to the appeal board. ${ }^{145}$ In both instances he is prejudiced by not being afforded an opportunity at the critical time to meet a deficiency in his claim. The problem is particularly acute where judicial review is, in all practical terms, limited to defense of a criminal prosecution. ${ }^{146}$

The courts have generally accepted an inference of insincerity based on delay in asserting a claim of conscientious objection. ${ }^{147}$ Most registrants brought up in the peace churches assert their claim at initial registration. ${ }^{148}$ Court cases involving the issue of delay, therefore, usually concern registrants whose affiliation with a peace church oc-

the time of his personal appearance to be principally concerned with "furthering his education by going to Europe and taking pictures." United States v. Gearey, 379 F.2d 915, 920 (2d Cir. 1967).

144 In United States v. Corliss, 280 F.2d 808 (2d Cir. 1960), the court drew a negative inference from the fact that letters from two ministers in support of the registrant's claim did not elaborate on the nature of the registrant's objection. See also United States v. Simmons, 213 F.2d 901 (7th Cir. 1954), rev'd on other grounds, 348 U.S. 397 (1955): "His claim was supported only by his own statement. No other members of the sect appeared in his behalf." 213 F.2d at 906.

A similar problem exists with respect to the ministerial exemption. In Wood v. United States, 373 F.2d 894 (5th Cir. 1967), the court expressed the view that the mere filing of a form in which registrant claims to be a "minister of Jehovah's witnesses," together with a written statement signed by the registrant and 5 persons attesting to the fact that registrant was a minister was insufficient to establish registrant's certification for the ministerial exception as a matter of law. Cf. Gatchell v. United States, 378 F.2d 287, 292 (9th Cir. 1967).

145 See Gonzales v. United States, 348 U.S. 407, 414-415 (1955).

146 See text at note 108 supra.

147 See United States v. Corliss, 280 F.2d 808 (2d Cir. 1960); Campbell v. United States, 221 F.2d 454 (4th Cir. 1955).

148 Cases described in note 139 supra. 
curred after initial registration. ${ }^{149}$ Where grounds for the claim exist prior to initial registration at the age of eighteen, it is reasonable to permit an inference of insincerity for failure to make the conscientious objection claim upon the initial filing of SSS Form 100. But such an inference should not be permitted merely because the registrant's belief was formulated after the age of eighteen or because the registrant delayed in asserting the claim until he had contact with his local board which brought the question of classification to his attention. It is unreasonable to expect someone who adopts a religious position over a period of time to be aware of the precise moment at which he may honestly make a formal application for exemption on the grounds of conscientious objection. He may genuinely not have considered the real significance of military service until contact with the draft board takes place, just as a new Jehovah's Witness may not consider the question of saluting the flag until he is first presented with the occasion. The realization through contact with the draft board that military service is a real possibility may be the factor which causes a young man "finally to crystallize and articulate his once vague sentiments."150 Once this contact has been made, however, it is not unreasonable to permit an inference of insincerity from failure to claim objector status at that point, but it should be emphasized that the inference is only permissible, not mandatory. There may exist perfectly valid reasons why the registrant has failed to assert his position as an objector on contact with the draft board.

A special problem is posed by non-assertion of a claim until shortly before or after receipt of the notice of induction. ${ }^{151}$ The same reasons for not permitting an inference apply here, but another factor comes into play which may justify the inference. There are discouraging social stigmas and legal disqualifications which attach to the status of conscientious objector. For example, in some places an objector may be denied admission to the bar ${ }^{152}$ or employment as a policeman. ${ }^{153} \mathrm{~A}$ young man who is not immediately faced with induction, and who may have reason to hope that he will never be called, will hesitate to assert an objector claim if he does not hold sincere beliefs. Moreover, beliefs

149 See United States v. Corliss, 280 F.2d 808, $811-12$ (2d Cir. 1960); United States v. Simmons, 213 F.2d 901 (7th Cir. 1954).

150 United States v. Gearey, 368 F.2d 144, 150 (2d Cir. 1966).

151 "The fact that [the registrant] made no effort to establish his claim until after he was ordered to report for induction suggests that he resorted to the expedient of filing a conscientious objector claim to evade military service . . . Parrott v. United States, 370 F.2d 388, 394 (9th Cir. 1966).

152 In re Summers, 325 U.S. 561 (1945).

153 See, e.g., IIL. Rev. StAT. ch. 24, \& 10-1-36 (1967). 
which arise shortly before induction do not carry the same persuasive quality as those held for a longer period of time. The latter in effect may be said to have withstood the test of time.

\section{An Assessment of Current Procedure}

The 1967 Act has altered the decision-making process in two respects, both of which are likely to be prejudicial to the registrant if not accompanied by some procedural changes. First, the focal point of the classification process has been shifted from a centralized reviewing agency in the Department of Justice to the local boards as to factual issues and to the appeal boards and state administrative headquarters as to the legal issues. The role of the local board under prior procedure was essentially preliminary in nature. The Supreme Court has described the role of the appeal boards under the old procedure, noting that "in contrast to the strictly appellate functions it exercises in other cases, the Appeal Board in handling conscientious objector claims is the first selective service board to receive the [Department of Justice's] recommendation and is usually the only decision-making body to pass on the entire file." 154 Since the appeal boards almost routinely accepted the Department of Justice recommendations, ${ }^{155}$ the Department in practice was the decision-making agency.

Second, the major evidentiary emphasis has been shifted from an FBI report containing relatively objective facts to evidence submitted by the registrant himself which must be appraised subjectively by the local board to determine its veracity. On the key issue of sincerity, documentary materials submitted by the registrant or other witnesses will only rarely permit an inference upon which sincerity may be determined, so that local boards will undoubtedly rely increasingly on an appraisal of the registrant in his personal appearance before the board.

Under prior procedure, with decision-making resting in the Department of Justice, determinations adverse to the registrant rarely rested on his statements or demeanor before the hearing officer ${ }^{156}$ Particularly where sincerity was at issue, it was the registrant's failure to explain adverse material in the FBI report satisfactorily that led to a negative recommendation. ${ }^{157}$ In this context, the availability to the reviewing

154 Gonzales v. United States, 348 U.S. 407, 413 (1955).

155 Gonzales v. United States, 364 U.S. 59, 72 (1960) (dissenting opinion). See also Rabin, supra note 7, 1967 Wis. L. Rev. at 650-51.

158 Cases described in note 139 supra.

157 Id. 
agency of only a summary rather than a transcript of the testimony before the hearing officer was not as serious an impediment to effective review as is lack of a transcript under current procedure, where the decision may rest largely on the oral testimony before the local board. Moreover, local boards staffed by laymen will not be able to develop the expertise of the attorneys who acted as hearing officers in the preparation of summaries that accurately reflect the relevant testimony.

Presently, most local boards are not preparing complete summaries of the testimony before them. The regulations probably do not require them to do so, but rather oddly leave it to the registrant to prepare a summary. Section 1624.2(b), referring to appearances before the local board, provides:

The registrant may present such further information as he believes will assist the local board in determining his proper classification. Such information shall be in writing, or, if oral, shall be summarized in writing by the registrant and, in either event, shall be placed in the registrant's file. The information furnished should be as concise as possible under the circumstances. ${ }^{158}$

Although this regulation uses the mandatory "shall be summarized in writing by the applicant," the provision is treated in practice as only permissive. Most files on appeal do not contain written summaries of oral testimony prepared by the registrant. ${ }^{159}$ In any case, considering the importance to the government of proper results on appeal, it seems inappropriate to allow the registrant, the interested party in the proceedings, to prepare the summary of testimony on which the appeal board must rely. Moreover, examination of the records reveals that many registrants lack the skills necessary to prepare complete or accurate summaries, and they are denied the right to have an attorney at their appearance. Section 1626.13(a) deals with preparation of records on appeal and expressly relieves the local board of any obligation to prepare a summary of testimony presented by or on behalf of the registrant. ${ }^{160}$

The current procedure thus creates an anomaly for both the appeal boards and the courts. Appeals to the appeal boards theoretically result in a de novo determination. If a local board in making its finding, particularly on the issue of sincerity, relied on oral testimony or the demeanor of the registrant, how can the appeal board assess the case

15832 C.F.R. § 1624.2(b) (1968).

159 Cases described in note 139 supra.

16032 C.F.R. $\S 1626.13$ (a) (1968). 
without full knowledge of what took place at the hearing before the local board? Some local boards have placed in the registrant's file a brief memorandum which may explain their decision and may contain a reference to some oral testimony. ${ }^{161}$ But such a brief and incomplete reference to testimony is hardly fair to the registrant who is supposed to be getting a de novo review. ${ }^{162}$ Registrants have no right to present any evidence or testimony personally before the appeal board; it may consider only evidence in the record received from the local board or general information concerning economic, industrial, and social conditions. ${ }^{163}$

The courts are faced with a similar problem. How can they affirm decisions where the record does not disclose some basis in fact for denial of the claim? Even if the local board has made some notation in the record of oral evidence which supports its decision, can courts properly perform their function of judicial review on a fragmentary record which may give an incomplete or distorted view of what took place in the administrative proceedings?

The remedy for this situation appears to be simple. With little effort and expense an audio recording could be made of all oral testimony before the local board. The appeal board could either listen to the recording or have a transcript prepared. If judicial review were undertaken a transcript of the recording could be prepared as part of the record. Such recordings could be made without serious inconvenience to the Selective Service System and would provide a completely reliable record for purposes of review as well as eliminating any question of accuracy that might otherwise arise. The latter point is particularly relevant where the proceedings before the local board are closed and the registrant is therefore unable to have witnesses in attendance who could subsequently corroborate his version of the testimony. The public as well as the registrant would have greater confidence in the essential fairness of the system if judicial review on a complete record were available.

A second change necessitated by the new procedure is a requirement that the local and appeal boards indicate the basis for their decisions in conscientious objection cases. This, too, is relatively simple; in fact, under the prior procedure, the practice was to give such an indication to the registrant.

161 See cases cited in note 76 supra.

16232 C.F.R. § 1626.26(a) (1968).

163 Id. § 1626.24(b). In addition, the registrant may present "any information which was offered to the local board and which the local board failed or refused to include in the registrant's file." Id. \& 1626.12 . 
The Department of Justice's letter of recommendation, which became part of the registrant's file, provided an explanation of the grounds for a recommendation adverse to the registrant. In addition to setting forth those facts deemed particularly relevant to the disposition of the case, the letter made one or more of the following findings: (1) the registrant's "opposition to war does not emanate from any religious tenets or beliefs"; (2) the registrant "is not sincere in his claim"; (3) the registrant's objection does not extend to all wars. ${ }^{164}$ Courts were generally willing to attribute the ground advanced by the Department of Justice to the appeal board. ${ }^{165}$

Neither the Act nor the regulations expressly requires indication of the basis for decision by the local or appeal board. It is questionable, however, whether a procedure which offers no explanation of the reason for official action meets the congressional intent to provide a system of selective service "which is fair and just," 166 an intent which has been construed to include fair and just procedures. ${ }^{167}$ The Supreme Court held that the requirement of a fair hearing under the procedure prior to the 1967 amendments gave registrants a right to receive a summary of the FBI report and full recommendations of the Department of Justice. ${ }^{168}$ These decisions rested on the premise that an appellate process which denies the appellant full knowledge of the basis of the action against him is inherently unfair. ${ }^{169}$ In Gonzales the Court said:

Just as the right to a hearing means the right to a meaningful hearing ...., so the right to file a statement before the Appeal Board includes the right to file a meaningful statement, one based on all the facts in the file and made with awareness of the recommendations and arguments to be countered..$^{170}$

In order for a registrant to exercise effectively his right to appeal under the current procedure, he should be advised of the basis of the decision denying his claim. The regulations grant the registrant the

104 Cases described in note 139 supra.

165 See cases cited in notes 118, 119 supra and accompanying text.

16650 U.S.C. APP. $\S 451$ (c) (1964), as amended by P.L. 90-40, 81 Stat. 100 (1967).

167 Gonzales v. United States, 348 U.S. 407, 417 (1955).

168 Gonzales v. United States, 348 U.S. 407 (1955); United States v. Nugent, 346 U.S. 1 (1953).

169 This is also the premise which underlies the holding of the Supreme Court in Willner v. Committee on Character and Fitness, 376 U.S. 96 (1963). The petitioner in that case was denied admission to the bar, ostensibly on the ground that he did not possess the "character and general fitness requisite for an attorney." The Court held that procedural due process required that petitioner be given the right to confront the person who had made adverse statements about him and be advised of the specific grounds for denying him admission.

170348 U.S. 407, 415 (1955) (emphasis added). 
right on his appeal to offer "a statement specifying the matters in which he believes the local board erred," and the registrant "may direct attention to any information in the registrant's file which he believes the local board has failed to consider or to give sufficient weight . . .".171 The regulations thus contemplate a "meaningful hearing"172 on appeal, but the lack of any indication of reasons for the local board's action frustrates achievement of this end. How can a registrant point out errors of the local board when he may not know the basis for their decision? The unfairness to the registrant is magnified because the law in effect limits judicial challenge to the administrative decision to defense of a criminal prosecution.

Equally important, the lack of any explanatory requirement at the administrative level will tend to lower the level of judicial review, particularly as to administrative misconstructions of the appropriate legal standard. Heretofore reviewing courts could reach questions of statutory construction whenever the Department of Justice recommendation was predicated upon a finding that the registrant's objection was not grounded on religious training and belief, even where the Department of Justice had also recommended denial of the claim on the alternative ground of lack of sincerity. ${ }^{173}$ Under the current scheme courts will presumably as a matter of first instance scrutinize the record for the necessary basis in fact. If there is any evidence in the record to support the denial of the claim on any of the three statutory grounds (religion, opposition to all wars, sincerity), the court will affirm the denial, possibly on a ground not relied upon nor even considered by the local and appeal boards. This means that an administrative practice which fails to articulate in any way the underlying rationale of the decision reached, coupled with a minimum standard of review which is limited to a search for a "basis in fact," will serve to obscure administrative errors of construction of the statute whenever a discernible basis in fact is present. The harm in terms of the loss of effective judicial review is particularly acute where experience has shown the controlling standard to be unusually susceptible to misconstruction.

Again, little inconvenience is involved in requiring local and appeal boards to designate, by checking on a form, which of the three grounds were relied upon in its decision. If a full record is available, as suggested above, then nothing else appears necessary. If the record is not available, local boards should also be required to indicate the eviden-

17132 C.F.R. § 1626.12 (1968).

172 Gonzales v. United States, 348 U.S. 407, 415 (1955).

173 United States v. Jakobson, 325 F.2d 409 (2d Cir. 1963), aff'd sub nom. United States v. Seeger, 380 U.S. 163 (1965); United States v. Englander, 271 F. Supp. 812 (S.D.N.Y. 1967). 
tiary basis for their finding to the extent it is not reflected in the written record of the case forwarded to the appeal board or the court in the instance of judicial review. ${ }^{174}$

\section{Conclusion}

As Chief Justice Vinson's remarks in United States $v$. Nugent ${ }^{175}$ indicate, the problem of devising procedures for selective service cases is unusually difficult. On the one hand, the demands of the nation for speedy procedures to meet the needs of mobilization for war or national defense are compelling. Allowing substantial delays to some contains an element of unfairness to others who may be called in their place. At the same time, we must recognize that selective service cases are literally dealing with men's lives. The problem increases manifold when we add to the issue the question of a person's religious beliefs and further try to ascertain the sincerity of those beliefs. Here the system touches what may be an individual's rawest nerve. The best procedure is one which strikes closest to the delicate balance between the governmental needs and the individual and societal interest in fairness.

The present system of adjudicating claims of conscientious objection has gone too far to the side of administrative ease and expediency. The shift from central to local decision-making responsibility removes expertise from the process and undermines uniformity of results. Both expertise and uniformity were present under the former procedures in the Department of Justice report. Furthermore, the decision formerly rested for its factual basis largely on a report of a comprehensive investigation of the registrant's background by the FBI. Today, the local board's decision inevitably rests primarily on facts it can garner from the registrant himself. Appellate review may now be effectively frustrated by the lack of an adequate record and the absence of any findings.

Although Congress by the 1967 amendments removed from the law the requirement that appeals be referred to the Department of Justice for inquiry, a hearing, and recommendations, it did not prohibit the continuation of the former practice. Instead it left to the President the

174 A requirement of this type would seem particularly necessary where the administrative decision has taken demeanor into account. Elaboration of the underlying facts would at least provide reviewing courts with some basis to assess the rationality of an inference that may have been drawn. The type of error that might be exposed by the elaborations of underlying facts is suggested by Quercia v. United States, 289 U.S. 466 (1933). There the Supreme Court reversed a conviction for violation of the narcotics act because the trial judge told the jury that "'wiping' one's hands while testifying was 'almost always an indication of lying." "

175346 U.S. I, 10 (1953). Quoted supra at note 1. 
task of devising procedures which strike the proper balance between the need for manpower and the demands of justice in individual cases. ${ }^{178}$ The former system did a reasonably effective job of striking this balance. The only criticism of it was that it was time-consuming, but the delays were essentially a manpower problem, easily correctable by an appropriation miniscule when measured by the 60 billion dollars devoted each year to defense.

There is no reason why a conscientious objector claim could not be processed from the local board through FBI investigation and through the Department of Justice and the appeal board in six months, not an excessive delay, and not significantly longer than under the current procedure. There may be a time when national emergency and total mobilization require faster action, but fortunately such a time is not upon us. As Justice Frankfurter said in United States v. Nugent:

The enemy is not yet so near the gate that we should allow respect for traditions of fairness, which has heretofore prevailed in this country, to be overborne by military exigencies. ${ }^{177}$

17650 U.S.C. APP. $\S 460(\mathrm{~b})(1)$ (1964), as amended by P.L. 90-40, 81 Stat. 100 (1967). 177346 U.S. 1, 13 (1953) (dissenting opinion). 